\title{
Rethinking the consumer metaphor versus the citizen metaphor: frame merging and higher education reform
}

Nordensvard, J., \& Ketola, M. (2018). Rethinking the consumer metaphor versus the citizen metaphor: frame merging and higher education reform. Social Policy and Society, 1-21.

https://doi.org/10.1017/S1474746418000465

Link to publication record in Ulster University Research Portal

Published in:

Social Policy and Society

Publication Status:

Published online: 26/12/2018

DOI:

$10.1017 / S 1474746418000465$

\section{Document Version}

Author Accepted version

\section{General rights}

Copyright for the publications made accessible via Ulster University's Research Portal is retained by the author(s) and / or other copyright owners and it is a condition of accessing these publications that users recognise and abide by the legal requirements associated with these rights.

\section{Take down policy}

The Research Portal is Ulster University's institutional repository that provides access to Ulster's research outputs. Every effort has been made to ensure that content in the Research Portal does not infringe any person's rights, or applicable UK laws. If you discover content in the Research Portal that you believe breaches copyright or violates any law, please contact pure-support@ulster.ac.uk. 
Rethinking the Consumer Metaphor versus the Citizen Metaphor: Frame Merging and Higher Education Reform in Sweden

\author{
Johan Nordensvärd* and Markus Ketola** \\ * Department of Political Science, Stockholm University \\ E-mail: johan.nordensvard@statsvet.su.se \\ ${ }^{* *}$ School of Applied Social and Policy Sciences, Ulster University \\ E-mail:m.ketola@ulster.ac.uk
}

Neoliberal metaphors of students often describe students as consumers, managers and even as commodities, but this analysis often disregards the discursive complexity of education. We argue that frame merging is essential to understand the hybrid modalities of neoliberal images of students in the Swedish context where the image of the student is suspended between a social democratic welfare service model, academic capitalism, new public management and welfare nationalism. We demonstrate this through the case study of introducing student fees for non-EU students in Swedish higher education, and how the merging of universal tax financing with a more individualised fee paying solution creates variegated and complex metaphors of students and higher education. These metaphors are infused with social democratic social citizenship, neoliberal reform of welfare services, academic capitalism and nationalist welfare chauvinism. This implies that in practice, it is nigh on impossible to disentangle the neoliberal consumer metaphor from that of social citizenship; instead they merge to generate multiple contextually relevant metaphors to fit the local debates in higher education.

\title{
Keywords: Higher education, Metaphors, Framing, Consumer, Citizens, Frame
}




\section{Introduction}

The neoliberal discourse has had a significant impact on how we understand both educational institutions and subjects, but how and why this is the case is not always clear. The dominant metaphor for the student in western society has been the metaphor of the consumer, while education providers are seen as corporations or service providers. This implies that higher education should be considered in market terms. As Wielemans argues, 'the metaphor of 'the free market', implying competition and the freedom of choice for consumers, has a strong normative impact' where 'economic considerations in particular are taking the lead, both in policy objectives (such as expenditure cuts and efficiency) and in the concepts adopted (such as management, productivity, etc.)' (2000: 33).

The existing literature on students as consumers resonates with Wielemans's observations. Todd et al. organise the literature around students as consumers into two groups, where the first group 'uses the notion of students as consumers in order to highlight the ways in which students are situated within a marketised system of higher education' while the second 'debates whether the notion of consumer is an accurate depiction of the role of students in higher education and offers alternative labels, concepts or strategies to more accurately reflect the relationship between post-secondary education and students' (2017: 543-544). Le Grand (2003) sketches out different social policy metaphors that are of relevance to students, when he describes the general relationship between service users and those delivering services, describing service users as either 'queens' who are able to make qualified choices between providers, or as 'pawns', who passively receive services delivered. In addition to the consumer metaphors demonstrated in Le Grand's work, an alternative to this is the notion of seeing students 
as both human capital and as managers of their own human capital. Human capital theory has been, at least superficially, been perceived as a reasonably viable policy discourse in the 1960s and 1970s where mass education explained rising access to higher education and a rise in whitecollar jobs. Even if times have changed, the human capital theory has been adapted in contemporary times to legitimise rising inequalities pointing to elite degrees leading to elite wages (Marginson, 2017).

Neoliberal thinking is therefore more about adapting a relatively stable core to new contexts, or, as Marginson describes it, about creating powerful metaphors to describe the relationship between education and work (Marginson, 2017) The human capital metaphor highlights, on the one hand, a neglect of other aspects of education, but on the other hand, it creates a strong belief that higher education degrees 'both allocate individuals in the labour market and to serve as job requirements throughout the occupational structure' (Baker, 2011: 6). Some of the core assumptions behind neoliberal metaphors (students as human capital, students as consumers) is to motivate certain core policy measures such as mass higher education, transfer of costs to students and a focus on increasing quality through competition between providers of higher education (Tight, 2013). We argue that the survival of neoliberal metaphors lies in understanding how neoliberal metaphors merge with the local contexts and policy debates.

These general policy metaphors can be applied in education policy to describe a neoliberal understanding of students. Nordensvärd (2010) in turn identifies three neoliberal roles that could be ascribed to students: students as consumers, students as managers of themselves and students as a commodity of human capital. Nordensvärd (2010) locates the social citizenship metaphor as a counter frame to the neoliberal metaphors but in his analysis the two metaphors remain siloed and separated from each other. Such analysis, we suggest, fails to reflect the 
discursive complexity of the education debates because it ignores the ways the metaphors, particularly in a neoliberal context, are in fact dynamic and highly integrated.

In order to address this complexity analytically, we start from the position that neoliberalism always exists in a variegated form as part of local welfare arrangements and never as a singular, universal entity. As Brenner et al. (2010: 332) argue, 'neoliberalization tendencies can only be articulated in incomplete, hybrid modalities, which may crystallize in certain regulatory formations, but which are nevertheless continually and eclectically reworked in context-specific ways'. In a similar fashion, Peck (2010) identifies neoliberalism as 'parasitical', constantly borrowing and building on other approaches and political ideologies - including social democratic and nationalist approaches investigated here. A neoliberal metaphor does not conjure up singular policies but rather generates multiple policy alternatives depending on the merging process. In our case the metaphor of the student is merged with a local understanding of social citizenship and welfare. The success of neoliberal metaphors lies in how these can integrate local understanding of citizenship into an overall understanding of students.

We argue therefore that frame merging is essential to understand the hybrid modalities of neoliberal metaphors of students in a Swedish context that consists of merging competing discourses. Metaphors are subordinated to particular ways of framing policies. We have used the case study of introducing student fees for non-EU students in Swedish higher education, a shift from universal tax financing towards a more individualised fee paying solution. In Sweden, student fees were introduced for non-European Union (EU) and European Economic Area (EEA) citizens in 2011. The state relinquished control over admissions and funding of non-EU students to the individual universities, symbolising another step away from a Scandinavian social democratic model and towards partial privatisation. The reforms have meant a fundamental shift in policy whereby universities are able to determine the level of overseas tuition fees, administer fees and 
develop programmes of study for overseas students. . This article will be one of the few that studies the discourse of introducing student fees for non-EU students.

The rhetorical and ideational debates around this reform allude to the ubiquity of the neoliberal approach to merging of frames that generates variegated metaphors incorporating both social democratic and nationalist ideas in ways that are meaningful in the Swedish context. In the context of the article we propose two such merged frames: competitive global social liberalism (emphasis on openness, attracting the best talent of the world and creating the global lecture room) and competitive welfare nationalism (charging international students addresses the social costs associated with a larger quantum of (international) students). These two merged frames create different neoliberal metaphors that support a neoliberal view of the policy and the world. In the article we demonstrate how competitive global social liberalism uses metaphors such as Investment, Enrichment and Social Development Aid to describe non-EU/EEA students. The merged frame of competitive welfare nationalism uses metaphors such as Free riders/Welfare tourists, Bad Investment, High End Consumers and Strategic Investment to describe nonEU/EEA students

However, importantly, we can see that the two merged frames and their associated metaphors support what Simons and Masschelein describe a transformation from social citizenship towards entrepreneurial citizenship with a concomitant shift from a welfare state towards a managing state where society is addressed as a 'complex of human and social capital in need of investment' and addresses 'fellow citizens as responsible learners and offers a learning infrastructure for enabling and facilitating learning.' (Simons and Masschelein, 2008: 406). We argue therefore that this discursive process is not an orthodox or pure process, but it is process of merging frames and discourses to fit the local context and discourse. Pure neoliberal metaphors of students exist mainly in theory. 


\section{Framing and metaphors}

In this article we are applying the method of interpretative social policy analysis to the strategies of framing neoliberalism as an approach to articulating policy problems and their solutions. Interpretative social policy analysis diverges from mainstream positivist policy analysis by focusing on how policy actors interact by addressing the social meaning of policies and the practices in which this meaning is embedded' (Durnova and Zittoun, 2011: 103). Moreover, such a perspective seeks to 'develop a deeper, interpretative understanding of policy practices and policy process in general, having extended their scope over time to include perspectives on discourse, narration, governmentality and practice' (Durnova and Zittoun, 2011: 103).

A discourse analysis approach tends to emphasise the indexical or situated nature of social categories in linguistic interaction' (Weatherall and Walton 1999: 481). A discourse analysis of policy could be understood to deconstruct texts to understand how texts are structured in a particular way and what social and political implications this will have (Jaworski and Coupland, 2000). Discourse analysis has an interest in how institutions and rules are spread through the use of language. A discourse does not primarily describe reality, but it constitutes it in a specific way (Keller, 2004: 63). The ways discourse is used as a theme are connected to power and coercion (Keller, 2005: 22). As Koller notes, '[d]iscourse is embedded in socio-cultural practice. Discourse constructs this context from a particular perspective and is, in turn, constructed by it' (2005: 200).

We will use a conceptual understanding of discourse in our analyses of frames, merged frames and metaphors. Metaphors need to be understood in the context of larger overarching frames. Frames, in turn, are seen as 'schemata of interpretation' that guide individuals 'to locate, perceive, identify, and label' events and conditions around them (Goffman, 1974: 21) and which is often used as a 'strategic and deliberate activity aimed at generating public support for specific 
policy ideas' (Béland, 2005: 11). Merged frames are then hybrids that comprise elements of each of the input schemas, but contribute to a new frame that becomes its own separate and unique structure (Fauconnier and Turner, 2002; Cornelissen, 2005). Metaphors are utilised to reinforce particular frames through particular applications. Metaphors are seen 'as devices or units of language that are deployed within particular conversations and contexts' (Cornelissen et al., 2008: 12). This sensitivity to context makes the approach suitable to 'informed interpretations about the specific uses of a particular metaphor in situ that may range beyond psychological or cognitive uses' (Cornelissen et al., 2008: 12).

Metaphors are not independent discourses but should be understood as direct embodiment of particular ideological frames. We see metaphors as both justification and embodiment of merged frames as something tangible. Merged frames and their related metaphors are variegated towards the local political context and therefore always adapted and contextualised in locally meaningful ways. Metaphors can represent both frames and merged frames where the former are an embodiment of a purer neoliberalism and the latter assuming a more variegated form. We have chosen this framework as it shows very well how a frame such as neoliberalism is contextualised to create multiple understanding of students and social citizenship. We have mapped the relationship between the concepts in Table 1.

\section{Table 1 Frames, frame merging and metaphors}

\begin{tabular}{|c|c|c|c|}
\hline Frames & Frame merging & Metaphors & The link \\
\hline $\begin{array}{l}\text { Frames are schemata of } \\
\text { interpretations that helps } \\
\text { to to locate, perceive, } \\
\text { identify, and label events } \\
\text { and conditions (Goffman, } \\
\text { 1974: } 21 \text { ). }\end{array}$ & $\begin{array}{l}\text { Frame merging is the } \\
\text { discursive combination of } \\
\text { two separate schemas or } \\
\text { incorporation of words and } \\
\text { elements of one schema } \\
\text { into that of another } \\
\text { (Fauconnier \& Turner, } \\
\text { 2002). }\end{array}$ & $\begin{array}{l}\text { Metaphors can be } \\
\text { considered as "a way of } \\
\text { comparing two different } \\
\text { concepts" (Jones and } \\
\text { Peccei, 2004: 46) and } \\
\text { understanding one } \\
\text { experience in terms of }\end{array}$ & $\begin{array}{l}\text { Frames, merged frame } \\
\text { and metaphors create } \\
\text { particular policy } \\
\text { contexts used to make } \\
\text { sense of particular } \\
\text { policy alternatives and } \\
\text { are part of the "exercise } \\
\text { of political power and } \\
\text { the language used to }\end{array}$ \\
\hline
\end{tabular}




\begin{tabular}{|c|c|c|c|}
\hline $\begin{array}{l}\text { Policy framing is a } \\
\text { strategic and deliberate } \\
\text { activity aimed at } \\
\text { generating public support } \\
\text { for specific policy ideas. } \\
\text { (Béland, 2005: 11). } \\
\text { Framing transcends the } \\
\text { boundaries of agenda } \\
\text { setting and links with } \\
\text { 'stable ideological } \\
\text { repertoires' (Béland 2005: } \\
2 \text { ). Policy makers need to } \\
\text { use culturally accepted } \\
\text { repertoires (Burstein, } \\
\text { 1998). } \\
\text { Frames are dialogical in } \\
\text { nature and anticipate } \\
\text { potential opposition to } \\
\text { undermine support for } \\
\text { policies (Béland, 2005: } \\
\text { 11). }\end{array}$ & $\begin{array}{l}\text { A merged frame is a hybrid } \\
\text { that comprises elements } \\
\text { from each of the input } \\
\text { schemas but also becomes } \\
\text { its own unique structure } \\
\text { (Cornelissen, 2005; } \\
\text { Fauconnier and Turner, } \\
\text { 2002). } \\
\text { Frame merging helps to } \\
\text { combine seemingly } \\
\text { incompatible and competing } \\
\text { sets of cultural beliefs } \\
\text { (Greenwood et al., 2011) } \\
\text { and circumvent the dilemma } \\
\text { of alternative and competing } \\
\text { schemas (Werner and } \\
\text { Cornelissen, 2014: 1457). }\end{array}$ & $\begin{array}{l}\text { Metaphors are chosen } \\
\text { to achieve certain } \\
\text { communication goals } \\
\text { within particular } \\
\text { contexts rather than } \\
\text { being predetermined by } \\
\text { bodily experience } \\
\text { (Charteris-Black, } 2004 \text { : } \\
\text { 247) which is aligned } \\
\text { with frames/merged } \\
\text { frames. }\end{array}$ & $\begin{array}{l}\text { Metaphors should be } \\
\text { understood as } \\
\text { embodiments of } \\
\text { particular ideological } \\
\text { frames. Metaphors both } \\
\text { justifiy and embody } \\
\text { merged frames as } \\
\text { something tangible. }\end{array}$ \\
\hline
\end{tabular}

\section{Higher education and national welfare policies}

The neoliberal discourse of students has been adapted to the local understanding of education and its relationship with local social citizenship and welfare arrangements. Education has a rather complicated role within a social policy discourse - it is both a tool to construct citizenship and at the same time it is in itself a social service. Education, from a citizenship perspective is often perceived to create and defend hegemony on the one side, and to provide opportunity rights as well as the bases for self-improvement and social renewal on the other. This dual nature of the education discourse within social policy has been seldomly discussed outright. 
For some scholars, the function of education is at the core of developing the nation state and, according to Green, education is both 'a valuable source of national cohesion and a key tool for economic development' (1997: 1). According to Sander (2005) one can talk about the direct ideological aspect of education, legitimating and protecting an existing social and political order from critique. All citizens need to be educated in comprehending the nation state's ruling values, or as Gramsci (in Giroux) would have put it: '[e]very relationship of 'hegemony' is necessarily an educational relationship' (Giroux, 2003: 101). National education was a tool in 'the formation of ideologies and collective beliefs which legitimate state power and underpin concepts of nationhood and national 'character"' (Green, 1990: 77).

The classical metaphors for students could be seen in national frameworks of students as citizens and as workers, with education as a cornerstone of progress and growth. McLaren suggests that schooling is an act of ritual performance and highlights here two important rituals: the rituals of becoming a citizen and the rituals of becoming a good worker (1986) in a 'disciplined and reliable workforce' (Morrow and Torres, 2000: 35-36). T. H. Marshall saw education as an important social right alongside welfare services (2006: 30). Brown (2001) argues that '[t]he idea of public education as a form of welfare or entitlement remains curiously absent from public policy analysis in the social sciences, even though it is a critical component of state legitimacy and of credentialing systems' (2001: 29).

There have been attempts to link higher education policy to the different welfare regimes (Pechar and Andres, 2011; Willemse and De Beer, 2012) and research has compared education with other areas of welfare policy in terms of public sector funding (Heidenheimer, 1981; Castles, 1989; Hokenmaier, 1998; Hega and Hokenmaier, 2002). In relation to social democratic higher education it has been argued that in cases such as Sweden, nations strive for 'a delicate balance between individual rights and the collective order' (Pechar and Andres, 2011: 31). 
Human capital formation has been perceived to happen between welfare structures on the one side and labour market policies on the other side, resonating strongly with the social democratic model (Pechar and Andres, 2011: 31). Subsequently, there is 'a certain degree of 'social engineering' in balancing and adjusting supply and demand of higher learning opportunities by fostering the development of both general and specific skills' through Numerus Clausus (Pechar and Andres, 2011: 47) on the one side and a commitment to de-commodification strategies which 'results in resistance toward introducing tuition fees' on the other, combined with high total expenditures for tertiary education (as a percentage of GDP) (Pechar and Andres, 2011: 47).

This shows an interesting twin commitment to both egalitarian values and high trust in what public administration can achieve. Indeed, it is the combination of these factors that leads to a willingness to accept high taxes (Pechar and Andres, 2011: 47). We need to understand the role of education within the Swedish welfare state in order to understand how neoliberal metaphors of students are adapted to these local contexts.

\section{Neoliberal metaphors of students}

Neoliberalism has a dialectical quality where, on the one hand, it is premised on rolling back the state, particularly by attacking the welfare state, while on the other hand, alternative state institutions are reigned in so as to manage the consequences of the earlier reductive policies. In short, this translates as exporting responsibility to the private sector while still funding and managing these activities. Although the increasingly privatised neoliberal government tends to 'steer rather than row' (Denhardt and Denhardt, 2000:549), it would appear that neoliberalism lives and regenerates itself through this contradiction, continually restructuring the state with the image of the small state as its aspiration, but never quite reaching that goal. 
How are these contradictions resolved by the neoliberal logic? The present-day drive behind neoliberalism is about identifying successful hybrid forms, coexisting with others, as a purely neoliberal world can never exist. This is the argument put forward by Peck when he describes neoliberalism in this sense parasitical - always requiring symbiotic relationships with other approaches, such as social democracy and nationalism - and identifies this as a key strength of neoliberalism (2010). What follows is that neoliberalism should be seen as a process that is associated with variegated forms, never to exist as singular (Peck et al., 2009), that takes different forms and builds different alliances in each country context.

This process consists of a series of challenging partnerships, with no simple trajectory, no single linear project. Neoliberalism has an endless capacity to reproduce and recreate itself and can be best described as a continuous process of transformation that is never complete (Peck, 2010: 7), constantly mutating in forms. We argue in this article that neoliberalism should be seen as a particular frame that is uniquely suited to hybridisation and frame merging as it guides our understanding and construction of policy and policy alternatives.

Neoliberalism gives individuals and groups a particular schema that is both clear but also open for interpretation. This has made neoliberalism attractive in the centrist discourse where both social democracy and conservatism have been able to unite within a neoliberal frame. It also allows, for example, contextual metaphors for students that combine neoliberal metaphors with local understanding of citizenship and social services. In contradiction to Nordensvärd (2010) neoliberal metaphors are not separate from citizenship metaphors but instead integrated and closely linked with local political debates and discourses.

We can see here, adapted to the Swedish context, three distinctive frames: the social democratic education frame (the student as a classless citizen/human); the neoliberal education frame (students as consumers, managers and human capital); and the welfare nationalism frame 
This article has been published in a revised form in Social Policy and Society

[https://doi.org/10.1017/S1474746418000465]. This version is free to view and download for private research and study only. Not for re-distribution, re-sale or use in derivative works. (c) Johan Nordensvard and Markus Ketola

(students as national citizens). Table 2 below offers summary of the three frames, the adjacent metaphors and the ideal education policy context associated with each. 
Table 2 Social policy frames and metaphors

\begin{tabular}{|c|c|c|c|}
\hline Social Policy discourse & Frame & Metaphor & Education \\
\hline $\begin{array}{l}\text { Swedish Social } \\
\text { education discourse }\end{array}$ & $\begin{array}{l}\text { Inspired by socialism and by the idea } \\
\text { that individual freedom was } \\
\text { supposed to be achieved through } \\
\text { the state. (Thörn and Larsson, 2012: } \\
263 \text { ). } \\
\text { Synonymous with the idea of } \\
\text { centrally organised 'one education } \\
\text { for all' Swedish citizens (Compare } \\
\text { Broady et al., 2000). } \\
\text { Universal rights to free education } \\
\text { and a public system of finance to } \\
\text { eliminate any debt constraints } \\
\text { through universal access to stipends } \\
\text { and loans. }\end{array}$ & $\begin{array}{l}\text { The students as classless } \\
\text { citizens/humans } \\
\text { A specific compromise between } \\
\text { economic liberalism and social } \\
\text { democracy (Hobsbawm, 1994: 270) } \\
\text { where equal citizenship creates a } \\
\text { sense of national identity, solidarity } \\
\text { and community (Marshall cited in } \\
\text { Titmuss, 1974). } \\
\text { Nordic universal and egalitarian } \\
\text { system creates social services that } \\
\text { are de-coupled from nationality or } \\
\text { ethnic origin, and do not discriminate } \\
\text { any citizens (Rothstein and Stolle, } \\
\text { 2003:196). }\end{array}$ & $\begin{array}{l}\text { Education is centralised, } \\
\text { universal service for all citizens. } \\
\text { The same education independent } \\
\text { from class, race or location. } \\
\text { The universities should not be } \\
\text { allowed to charge tuition fees. } \\
\text { The state should provide each } \\
\text { student with a modicum of } \\
\text { financial support (Björklund et al., } \\
\text { 2004). }\end{array}$ \\
\hline $\begin{array}{l}\text { Swedish Neoliberal education } \\
\text { discourse }\end{array}$ & $\begin{array}{l}\text { Merges local social democratic } \\
\text { welfare premises where individual } \\
\text { freedom becomes dependent on } \\
\text { emancipation from the power of the } \\
\text { state. (Thörn and Larsson, 2012: } \\
\text { 264). } \\
\text { A change in welfare discourse } \\
\text { fuelled by 1990s economic crisis in } \\
\text { Sweden led to a dominant } \\
\text { perception of need to restructure the } \\
\text { welfare system (Boréus, 1994; } \\
\text { Ryner, 2002; Belfrage and Ryner, } \\
\text { 2009) around processes of } \\
\text { marketization, responsibilization and } \\
\text { market actors. }\end{array}$ & $\begin{array}{l}\text { The students as consumers and } \\
\text { human capital } \\
\text { New Public Management in general } \\
\text { and cost benefit assessments in } \\
\text { particular tend to portray students } \\
\text { and tax payers as consumers who } \\
\text { want most value for their money. } \\
\text { Students may consume educational } \\
\text { services for her/his own pleasure } \\
\text { and interest or improving her/his } \\
\text { position on the labour market as a } \\
\text { knowledge worker and a self- } \\
\text { regulated learner (Nordensvärd, } \\
\text { 2010) }\end{array}$ & $\begin{array}{l}\text { Education and knowledge as } \\
\text { tools that nation states use to } \\
\text { compete with other countries in } \\
\text { the international marketplace } \\
\text { (Porter, 1990; Drucker, 1993). } \\
\text { Universites as key sites for } \\
\text { investing and managing human } \\
\text { capital where the Social } \\
\text { Investment State ensures that } \\
\text { education is wisely invests in } \\
\text { human capital and that the } \\
\text { educational outputs produce real } \\
\text { economical growth } \\
\text { (Nordensvärd, 2010). }\end{array}$ \\
\hline
\end{tabular}




\begin{tabular}{|c|c|c|c|}
\hline & $\begin{array}{l}\text { Impact of the popular New Public } \\
\text { Management discourse focused on } \\
\text { efficiency, cost-savings and } \\
\text { decentralisation on education (Politt } \\
\text { and Bouckaert, 2004). }\end{array}$ & $\begin{array}{l}\text { Informed by a knowledge economy } \\
\text { frame that sees the nation state and } \\
\text { individuals as managers and } \\
\text { producers of human capital } \\
\text { competing on a global scale with } \\
\text { other countries/individuals (Fougner, } \\
2006 \text { ). }\end{array}$ & \\
\hline $\begin{array}{l}\text { Swedish welfare nationalist } \\
\text { discourse }\end{array}$ & $\begin{array}{l}\text { The rise of welfare nationalism } \\
\text { creates a boundary between } \\
\text { perceived citizens and non-citizens in } \\
\text { priming the interests of the native } \\
\text { 'common man' (de Koster et al., } \\
\text { 2012: 4). } \\
\text { Welfare nationalism argues against } \\
\text { welfare for foreigners and the elitist } \\
\text { construction of welfare neglects the } \\
\text { interests of the 'common man' } \\
\text { (Nordensvärd and Ketola, 2014). } \\
\text { Welfare chauvinism implies a strong } \\
\text { support for economic redistribution } \\
\text { with resistance toward distributing } \\
\text { welfare services to immigrants (Van } \\
\text { der Waal et al., 2010) and that } \\
\text { 'welfare services should be restricted } \\
\text { to our own' (Andersen and Bjørklund, } \\
\text { 1990: 212). }\end{array}$ & $\begin{array}{l}\text { Students as national ethnic } \\
\text { citizens } \\
\text { Students as first and foremost as } \\
\text { national ethnic citizens in contrast } \\
\text { with non-citizens such as asylum } \\
\text { seekers, refugees and migrants } \\
\text { (Nordensvärd and Ketola, 2014). } \\
\text { A perceived conflict between the } \\
\text { ethnic citizen and elites, who } \\
\text { disregard the interest of } \\
\text { citizens/taxpayers and create a } \\
\text { social citizenship geared towards } \\
\text { asylum seekers, refugees, migrants } \\
\text { or even welfare scroungers } \\
\text { (Nordensvärd and Ketola, 2014) } \\
\text { Solidarity is not universal but based } \\
\text { around a perceived or felt } \\
\text { homogeneity and an idea of "us" } \\
\text { against 'them")' (Hjerm and } \\
\text { Schnabel, 2012: } 347 \text { ) where nation } \\
\text { state is 'one of the most important } \\
\text { organizational entities for social } \\
\text { solidarity' (Mau and Burkhardt, 2009: } \\
\text { 214). }\end{array}$ & $\begin{array}{l}\text { Education is a service that should } \\
\text { be first and foremost enjoyed by } \\
\text { national citizens and directly } \\
\text { related to a perceived interest of } \\
\text { the in-group in comparison to an } \\
\text { out-group. } \\
\text { Education is also seen as } \\
\text { fundamental to creating a } \\
\text { perceived shared identity and } \\
\text { community which starts from, and } \\
\text { is an extension of, the nation } \\
\text { state. }\end{array}$ \\
\hline
\end{tabular}




\section{Methodology}

As a case study we have chosen the reforms of higher education in Sweden where student fees were introduced in June 2011 for non-EU/EEA students; this has led to both a commodification of education for overseas students and a decentralisation of the governance of higher education. The tuition fees are administrated by individual universities. Universities are responsible for attracting non-EU/EEA students and creating unique programs for them. This has meant, to some degree, a part-privatisation of universities where there is no room for a uniform higher education service for all citizens and talented overseas students. Higher education was chosen as a case study for the following reasons: Admissions to higher education in Sweden are still largely centralised and higher education was, until the implementation of the reforms, free to all students (including those from overseas). Until 2011, Sweden was an exception to the norm in that overseas students could study in higher education without any fees. The discourse was the amount of free movers from non-EU/EEA have reached unsustainable levels. In the academic year of 2010/2011 there was on 19000 students (PhDs not included) from non-EU/EEA countries that did not belong to any organised exchange program (so called free movers). Added to that were around 7000 free movers where origin was unknown. In the next academic year there was only 1350 paying students registered which meant that only 29 per cent of students accepted their offer. The Swedish universities had accepted 4600 fee paying students (Kahlroth, 2012)

The tuition fees for non-EU/EEA students were implemented in Sweden during a conservative government, but the initiative came from the preceding social democratic minority government of Prime Minister Göran Persson. The proposal was drafted and enacted through the subsequent centre-right government demonstrating a continuity of the policy discourse.

In researching the framing process around the introduction of student fees for international students we have used three main data sources: official documents and texts from the government such as: 'Competing on the basis of quality - tuition fees for foreign 
students' (Government Offices of Sweden, 2009) and the 'Fact sheet Competing on the basis of quality - tuition fees for foreign students' (Government Offices of Sweden, 2010). In addition, the research focused on recently published interviews, newspaper articles and opinion pieces from leading participants in the discussion that further clarify the different positions on student fees. The texts analysed can be found in Table 3 .

Table 3: Empirical material

\begin{tabular}{|c|c|c|}
\hline Document Type & Qty & Title \\
\hline $\begin{array}{l}\text { Governmental } \\
\text { Document }\end{array}$ & 5 & $\begin{array}{l}\text { - Competing on the basis of quality - tuition fees for foreign students } \\
\text { (Government Offices of Sweden, 2009) } \\
\text { - Fact sheet Competing on the basis of quality - tuition fees for foreign } \\
\text { - Atudents (Government Offices of Sweden, 2010) } \\
\text { - Advantage Sweden - en kraftsamling för ökad rekrytering av utländska } \\
\text { - Studenter till Sverige (SOU, 2000) } \\
\text { - Konkurrera med kvalitet - studieavgifter för utländska studenter } \\
\text { (Governmental Bill, 2009) }\end{array}$ \\
\hline Op-ed /Editorials & 11 & $\begin{array}{l}\text { - } \quad \text { Kunskapsexport lyfter landet. (Andersson and Törnvall, 2001) } \\
\text { - Gör utbildning avgiftsfri för utländska studenter (Christensson, 2015) } \\
\text { - Avgifter ger sämre studiekvalitet (Lundgren, 2010) } \\
\text { - Studieavgifterna gör svenska lärosäten isolerade, Svenska Dagbladet } \\
\text { (Nilsson, M., Danielsson, J., Ericson, M. Wanngard, K and Arroy, E., } \\
\text { - } \text { Ingen vilja att internationalisera (Mörck, Hanna Victoria, 2010) } \\
\text { - Avgift på högskolan bör tas bort (Wanngård, K., 2012) } \\
\text { - Avgifter slår mot utomeuropeiska studenter (Åkesson, Weibull, Sahlin } \\
\text { - Stärk högskolans internationella konkurrenskraft (Östros, 2004) } \\
\text { - Skrämmande syn på högskolan (Östros, 2001) }\end{array}$ \\
\hline $\begin{array}{l}\text { News Article/Press } \\
\text { release }\end{array}$ & 6 & $\begin{array}{l}\text { - Sverige inför avgifter men gör inget för att locka studenter } \\
\text { (Mälardalens högskola, 2010) } \\
\text { - V och mp går emot s-förslag om avgift för utlandsstudent (Svenska } \\
\text { Dagbladet, 2004) } \\
\text { - Inte längre gratis studera i Sverige (Svenska Dagbladet, 2008) } \\
\text { - Centerpartiet förväntas vilja slopa avgifter för utländska studenter } \\
\text { (Svenska Dagbladet, 2011) } \\
\text { - (S) vill slopa avgifter för utländska studenter (Sveriges Radio } 8 \text { April, } \\
\text { 2013) } \\
\text { - Socialdemokraterna föreslår förändring av studieavgifter, } \\
\text { (Universitetsläraren, 2013) }\end{array}$ \\
\hline
\end{tabular}


We have done a discourse analysis using frames and metaphors as presented earlier. We used the following rationale in choosing the public documents for our main analysis. First, these are the public documents used by the education minister and the Department of Education in framing the proposed policy. These documents have been published on the homepage of the government webpages and therefore also represent the official framing of the proposed policy. Second, these documents therefore tell us what frames are used to legitimise a departure from tax-financed higher education in Sweden. Third, these documents are aimed at persuading the public about the importance of policy change and are, therefore, carefully crafted to highlight those frames that are seen to support policy change among the public.

An additional focus of the discussion has been on published interviews and opinion pieces from leading stakeholders in the debate concerning student fees for non-EU/non-EEA citizens. The criteria for selecting such documents for the analysis concern their relevance for demonstrating different positions to the introduction of student fees for the bespoke group and usage of discourse to motivate their position.

The selection has been based on capturing the dominant positions within the policy reform in question, and the selection we have used as a sample is presented in Table 3 above. In so doing, we have read through most publications, news article and publications on the topic until we have reached a limit on new perspectives, or a saturation point. A possible source bias in this research can be identified in our exclusion of private blogs, online discussions forums and other similar sources. In addition, the overall discussion available on this topic has been relative limited, meaning there is limited breadth of material and discussion available.

We have completed a text analysis by using the concepts presented in Tables 1 and 2, applying these to the material identified in Table 3. We are convinced that we have covered most of the different perspectives presented in the discussion, but there will always be room to create new merged frames and metaphors depending on how the discourse will develop the coming 
years. We remain convinced that by using our methodological concepts that a researcher will come to similar conclusions as those we make, and that our conclusions are representative.

\section{Merged frames and applied metaphors}

We find in the study that there are two diverging merged neoliberal frames that either support or oppose this particular policy. We argue that we can only understand the different applied metaphors in relation to the merged frame used. The frames in question are: 1 Competitive neoliberal welfare nationalism (we become competitive by charging international students who have become a financial burden, who have decreased the educational quality and have attracted international educational tourism) and 2 Competitive and global social liberalism (we become competitive by being open and attractive to the best talents of the world and creating the global lecture room). The first approach supports fees for non-EU students in Swedish higher education whereas the second one opposes this. One could argue that neoliberalism is used as a 'docking station' where competing merged frames and applied metaphors could be locked in to support and oppose particular forms of policy change. The Swedish case shows how neoliberalism becomes the docking station for arguments located on both sides of the debate around international student fees. Each merged frame will produce different metaphorical understanding of the students showing both the complexity of how neoliberalism is understood in local context and its impacts on how we understand students from a neoliberal perspective. We have created an overview of our merged frames and applied metaphors which can be seen in table 4 . 
Table 4 Merged frames and applied metaphors

\begin{tabular}{|c|c|c|c|}
\hline \multicolumn{2}{|c|}{ Competitive and global social liberalism } & \multicolumn{2}{|c|}{ Competitive neoliberal welfare nationalism } \\
\hline Types & Metaphors & Type of students & Metaphors \\
\hline Non EU/EEA students & $\begin{array}{l}\text { Strategic Investment: Investing in } \\
\text { foreign students by having fees will } \\
\text { lead to better (economic and social) } \\
\text { relationships with important } \\
\text { developing countries. It is also seen } \\
\text { as a discounted investment in } \\
\text { students who have already been } \\
\text { educated in their homelands. } \\
\text { Enrichment: The students will } \\
\text { create a global classroom where } \\
\text { national students can learn from the } \\
\text { international students and } \\
\text { themselves become global players. } \\
\text { It is also about attracting the } \\
\text { smartest brains on a global scale to } \\
\text { make Sweden globally competitive. }\end{array}$ & Non EU/EEA students & $\begin{array}{l}\text { Free riders/Welfare tourists: There } \\
\text { are students that could pay but are } \\
\text { only coming to Sweden because it is } \\
\text { free and thereby induce costs that } \\
\text { will decrease the quality. } \\
\text { Bad investment: The added value } \\
\text { of these students does not } \\
\text { compensate for the costs they add to } \\
\text { higher education. These costs could } \\
\text { be invested into raising the quality. } \\
\text { High End Consumers: There is a } \\
\text { need to see non EU/EEA students } \\
\text { as high end consumers that are } \\
\text { willing to pay for high quality } \\
\text { education and these high fees could } \\
\text { go into creating a high end product. } \\
\text { Strategic investment: There needs } \\
\text { to be a more efficient scholarship } \\
\text { system to attract people who could } \\
\text { not pay and have they skills that } \\
\text { Sweden need. }\end{array}$ \\
\hline
\end{tabular}




\begin{tabular}{|l|l|l|l|}
\hline Nationals/ EU/EEA students & $\begin{array}{l}\text { Global workers: The local students } \\
\text { can learn from international students } \\
\text { in a global lecture preparing them for } \\
\text { the global labour market. } \\
\text { Global connectors: The national } \\
\text { students need to be connected to } \\
\text { the world instead of being isolated. } \\
\text { International students can make } \\
\text { these connections for themselves } \\
\text { and the country. }\end{array}$ & $\begin{array}{l}\text { Nationals/ EU/EEA students } \\
\text { used in a rather wide sense as this } \\
\text { includes not just Swedish citizens } \\
\text { but also all EU/EEA which are not } \\
\text { directly contributing through taxes. } \\
\text { Consumers: Both the students and } \\
\text { the tax payers are seen as } \\
\text { consumers that need to get the most } \\
\text { value for money from an investment } \\
\text { in higher education } \\
\text { Human capital: If Sweden is going } \\
\text { to become competitive, it will need to } \\
\text { have the best education and this can } \\
\text { only be done if the state invests } \\
\text { more efficiently in National/EU/EEA } \\
\text { students. }\end{array}$ \\
\hline
\end{tabular}




\section{Merged frame: competitive neoliberal welfare nationalism}

The government used the frame of competitive neoliberal welfare nationalism to support its proposed policy of student fees for international students. We can see a neoliberal frame that integrates both social democratic citizenship and welfare nationalism to steer our understanding of national and overseas students. This merged frame creates a particular focus on seeing students as either national students (citizens, consumers, human capital) or as international students (free riders/welfare tourists, bad investment and high-end consumers). The starting point here is defining the difference between EU and non-EU students and this is done by using the metaphor of citizens and non-citizens. This is of course metaphorical as the students are not only Swedish citizens but also EU/EEA citizens who do not directly contribute through taxes. It is about widening the concept of national rights and duties to welfare to countries within the EU/EEA. It is important therefore for the government that the metaphor of national citizenship is not endangered through this policy change.

Hence we find reassurances that Swedish and European students will still enjoy 'the rights to free education.' In the centre-right government bill entitled 'Competing on the basis of quality tuition fees for foreign students' the government proposed that 'higher education should [only] be free of charge for Swedish citizens and citizens of an EU/EEA state or Switzerland.' (Government Offices of Sweden, 2010: 1). This consensus in the debate echoes the overall importance of keeping higher education as a citizenship right for those seen as citizens.

The second metaphor used heavily is seeing the national student as human capital. The centre-right government $(2006$ - 2014) linked the reforms to the concept of Sweden competing in the knowledge economy with a need to invest radically into education and research in order to maintain high levels of economic growth and to improve Swedish welfare. The focus on Sweden's ability to maintain and develop welfare is, according to the government, dependent to a large extent on Sweden's ability to manage knowledge'(Government Offices of Sweden, 2010). The government also opined that a 'well-educated population is crucial for a country wanting to assert 
itself in the face of ever tougher global competition' (Government Offices of Sweden, 2010). The knowledge economy frame is used as a starting point to identify priorities, such as the need to invest in human capital to be able to take advantage of the knowledge economy, and here tuition fees from non-EU/non-EEA students are framed as the central means that will help achieve this goal.

The metaphors used for understanding the non-EU students show how both the merged neoliberal frame adapted to particular policies but also to a particular understanding of neoliberalism expressed in the metaphor of non-EU students as free riders/welfare tourists. The government has used welfare nationalist arguments that discredit some international students as free riders and a burden that decreases the quality of the education. The centre-right government talked rather openly about the negative effects of free education: it referred to an enquiry among third country students according to which their main motivation to study in Sweden is the absence of student fees. This motivation, the government argues, have led to a far lower degree of academic quality among third country nationals. Following this logic, the introduction of fees would attract a higher calibre of overseas students and improve the quality of education in general, without increasing the burden on the taxpayer. Instead of recruiting people who do not want to pay for their education, the government argues, institutions can today recruit highly motivated and able third country students more effectively through tuition fees (Government Offices of Sweden, 2010). This argument can be interpreted as a variation on the theme of 'welfare tourism', which suggests foreign nationals are motivated by the fact that welfare services, such as education, are free.

Sometimes the metaphors for students are directly linked to each other. For example, when the government describes students from non-EU countries as bad investment, it also implies that national taxpayers and also national students are consumers. Interesting here is that EU citizens are left out of the national discourse as one could also see they would add costs to the Swedish Higher Education (SHE). Moreover, there are a general understanding of tax payers 
as educating students are in a general interest of all tax payers (notwithstanding students as future taxpayers).

The government argues that the rise in international students in SHE has spiralled out of control. They argue further that the number of students applying to study across national borders has risen dramatically throughout the world over the past ten years. The number of students coming to study in Sweden has trebled since 1999, and these students currently make up just over eight per cent of the student population in Sweden (Government Offices of Sweden, 2010: 1). The international students are portrayed as an extra burden for the Swedish taxpayer (SOU, 2006). The costs involved in admitting these students have risen significantly given the sheer numbers of overseas students entering. The official report of the government, Studieavgifter $i$ högskolan (SOU, 2006: 7, 9) suggested that the benefit of increased diversity through international students is not reason enough to offer free tax-financed education to international students (SOU, 2006: 7, 21; Government Offices of Sweden, 2010: 1).

The government therefore argues that Swedish tax revenues should primarily cover the educational needs of Swedish citizens (Government Offices of Sweden, 2010: 1), making students from non-EU countries a bad investment for the Swedish citizen consumers. The sensible way to improve the quality of non-EU students and the overall quality of education is to understand the fee-paying non-EU student as high-end consumers (Government Offices of Sweden, 2010: 1).

\section{Competitive and global social liberalism}

We have shown in the previous section that merged neoliberal frames also create adapted metaphors that are used to support a particular policy. This means, in other words, that neoliberal metaphors for students are far more complex, ambiguous and contextualised. When we look at the opposition to introducing fees for non-EU students we can find competing merged neoliberal frame which we call 'competitive and global social liberalism'. Whilst framing the issue differently, 
it needs highlighting that the initial idea to introduce student fees for international students in fact originates in Social Democratic education policy. The Swedish government and the education minister Thomas Östros enforced a compromise in pursuing fees for non-European students while arguing that fees for national/European students would enhance social biases in recruitment of students and be in opposition to egalitarian higher education financed through taxation (2001). The party has since then largely distanced themselves from student fees for international students and subscribed, at least in writing, to a neoliberal competitive and global social liberalism that concludes the benefits outweigh the costs of having free higher education for international students. In practice there has been little plans to lift the fees since the Social Democrats and the Green Party have formed a minority government in 2014.

This merged frame agrees upon seeing the national student as a citizen but also applies a metaphor - national students as human capital in need of investment. The big difference is in the metaphor of non-EU students as strategic investment. Karin Wanngård from the Social Democratic Party in Stockholm argued before the electoral win of 2014 that the removal of overseas student fees should be a priority for any future social democratic government. She suggests that Sweden suffers from a natural competitive disadvantage compared to a country such as Australia that is English-speaking, has a warmer climate and is closer to many of the desired Asian students, which challenges the attractiveness of the Swedish education product. According to Wanngård, the connections with the rest of the world that overseas students bring are vital for export-oriented countries such as Sweden. Overseas students should therefore be seen as an investment (Wanngård, 2012). Such an argument implies that higher education increases Sweden's influence through soft power, where students start to identify with their host country and will influence their home country or home networks to be in favour of their host country (Lomer, 2017).

The party have since then moved between wanting to abolish the system of student fees for international students and wanting to just reform the existing system (Sveriges Radio, 2013). 
The main fraction of the Social Democratic Party has professed a change of the fee system to make it more differentiated according to the needs of the nation state. Ibraham Baylan, educational spokesman for the party, said before the election 2014, that it should be a priority for universities to gain attractive international students that would contribute both to Swedish Higher Education and the Swedish economy (Universitetsläraren, 2013).

Other actors highlight that overseas students are an investment in Sweden's competitiveness in the global market, in turn implying that the reformed education policy is a bad investment. Fredrick Federley from the Centre Party argues that this is all about achieving a multinational environment in the higher education institutes and keeping the level of research and the academic discourse at a high level. He argues that Sweden is part of the global competition for 'smart brains' (Svenska Dagbladet, 2011). Christensson (2015) argues that this is done through an international approach to higher education; there is therefore a need to remove student fees for international non-EU students.

The argument that student fees have stopped the process of internationalisation and made SHE isolated in a global world has also been put forward. In an op-ed Magnus Nilsson, from the Social Democratic student federation, and others argued that the introduction of student fees led to a decrease of 79 per cent of international students and the scholarship system set up to address this has been flawed and inadequate (Nilsson et al., 2013). The authors focus on Sweden as being a small northern European country that needs to look outwards whereas rest of Europe looks inwards (Nilsson et al., 2013).

A second metaphor depicts the international student as an enrichment for the local students who would become more competitive in the global knowledge economy. For example, the pro-directors from four of the largest SHE institutes, Lund, Göteborg, Uppsala and Royal Institute of Technology in Stockholm, have argued in the Swedish newspaper Sydsvenskan that overseas students will make native students more competitive in the global market. In a op-ed they argue that the Swedish students have had the possibility to be in a global classroom which 
has prepared them for the international labour market (Åkesson et al., 2011). The argument that student fees have stopped the process of internationalisation and made SHE isolated in a global world has also been put forward

\section{Discussion and conclusion}

We can see that neoliberalism and neoliberal metaphors are seldom as clear cut as in Nordensvärd's typology (2010). By being adapted and contextualised they are transformed to fit the local context. For example, in the Swedish case both merged neoliberal frames agree upon seeing the national students first and foremost as citizens. One of the arguments against student fees for overseas students is based on the principle of education being a citizenship right and not a commodity. By introducing fees this will turn education into a marketised product. Mörck states that 'education is a right, not a commodity' (2010). The Left Party (Vänsterpartiet) and the Green Party (Miljöpartiet) highlight that education is a right for everyone (Universitetsläraren, 2013). Elin Rosenberg from the United Swedish Student Unions (Sveriges förenade studentkårer) specifically argued that the introduction of fees for overseas students turns education from a right to a commodity, suggesting that this will open up the possibility of fees even for Swedish students (Svenska Dagbladet, 2008).

This fear of student fees is shared by others in the debate, such as Lundgren (2010), perceiving the student fees for international students as a Trojan horse that could eventually introduce student fees for Swedish students as well. The overall linkage between quality and student fees were part of an on-going debate where some of those opposing the policy, such as the MP Yvonne Andersson and Professor Anders Törnvall argued that student fees should be applicable for all students as the quality was falling behind other countries and that student fees would lead to an increase in quality (2001). The rise of the Sweden Democrats might highlight a larger of focus on welfare nationalism (Nordensvärd and Ketola, 2015) but there is no evidence that the success of the party will change the overall discourse of neoliberalism. It is to assume 
that it will strengthen the argument of non-EU students need to pay for education vis-à-vis the overall understanding of education as primary something for nationals. The variegated forms of neoliberalism have been able to incorporate welfare nationalism into their discourses to different degrees and create different metaphors for understanding students in general and international students in particular in ways that are at the same time locally relevant as well as ambiguous.

In a neoliberal discourse where the state and private enterprise become interwoven in discursive and social practices, we see how images of students and images of citizens become interlinked. Alvesson (2006) points to the problematic discursive role of contemporary understanding of education, as a being able to solve both economic and social problems. Alvesson discusses these beliefs as the fundamentalism of education, which means a naïve trust in education as a general problem solver, and as inherently good where work skills are fostered in education, and where low levels of education are regarded as an individual deficit. Alvesson means that the values and expectations of education are one of our most predominant myths with an almost fetishised notion of competence and knowledge (2006: 50-51). We argue here that the same discussion could be held about citizenship, as education and citizenship are closely intertwined.

We argue that market metaphors for students are intricately interlinked with our understanding of social citizenship. As stated earlier, education itself has always been linked to both construction and reproduction of national citizenship and a reliable workforce. Any change of our understanding of social citizenship will also have a direct impact of how we understand education and vice versa. We could therefore see in the Swedish case a more pronounced economic understanding of citizenship as has also been argued by Simons and Masschelein (2008). They argue that education has become part of an economic citizenship where learning is a form of (employable) capital, as a responsibility, and as a domain of management. When we discuss higher education, we can now see it as part of an entrepreneurial self government (of professionals, citizens, employees, organizations, societies) or autonomy, according to the 
'nomos' of the permanent economic tribunal. We understand learning as a process aimed at producing human capital or adding value to the self (and for oneself as a consumer or for others (Simons and Masschelein, 2008: 407-408). This leads to a government whose rationality is based on an 'economization of the social' and 'the main horizon for governmental reflection is no longer social but economic' (Simons and Masschelein, 2008: 406).

What this article does is highlight that this process should not be seen discursively uniform or straightforward, but as something that adapts to local both social and economic citizenship due to local mixed economy of welfare and the particular context of local welfare state arrangements. So even if we could see a general understanding of students through neoliberal metaphors, in practice and policy these metaphors are often contextualised in local discourses of welfare arrangements.

What this article therefore shows is that such processes have variegated starts and ends and restart points. There is not one homogenous way of creating this 'economization of the social' but myriad hybrids. In particular, it brings to the fore the role 'impure' hybrid logics play in the survival of the neoliberal consensus. As such we argue that frame merging is at its most persuasive when modelled as edifications or reinterpretations of existing ideological positions. The alternative discourse on tuition fees in Sweden highlighted education either as a universal social right that problematised the view of education as a commodity, or as an exclusive social right limited to Swedish citizens.

The discussed variegated forms of neoliberalism has two ways to reframe the nation state as a key site for defining and re-defining citizenship in a world where is predominantly understood through both economic and nationalist terms. This means that neoliberal metaphors can in practice not be separated from citizenship metaphors/social policy but are merged to spawn contextual metaphors to fit the local social policy debates on higher education. 


\section{References}

Åkesson, Weibull, Sahlin and Malmström Jonsson (2011) 'Avgifter slår mot utomeuropeiska studenter', Sydsvenskan, 28 June.

Alvesson, M. (2006) Tomhetens Triumf. Om Grandiositet, Illusionsnummer och Nollsummesspel, Stockholm: Atlas.

Andersen, J. G. and Bjørklund, T. (1990), Structural changes and new cleavages: the Progress Parties in Denmark and Norway, Acta Sociologica, 33, 2: 195-217.

Andersson, Y. and Törnvall, A. (2001) 'Kunskapsexport lyfter landet', Svenska Dagbladet, 23 August.

Baker, D. P. (2011) 'Forward and backward, horizontal and vertical: transformation of occupational credentialing in the schooled society', Research in Social Stratification and Mobility, 29, 5-29.

Béland, D. (2005) 'The politics of social policy language', Social Policy and Administration, 45, 1, $1-18$.

Belfrage, C. and Ryner, M. (2009) 'Renegotiating the Swedish social democratic settlement: From pension fund socialism to neoliberalization', Politics and Society, 37, 2, 257-88.

Björklund,A, Edin, P-A., Fredriksson, P. and Krueger, A. (2004) The Market Comes to Education in Sweden: An Evaluation of Sweden's Surprising School Reforms, Uppsala: Uppsala University.

Boréus, K. (1994) Högervåg: Nyliberalism och Kampen om Språket i Svensk Debatt 1969-1989, Stockholm: Tidens förlag.

Brenner, N., Peck, J. and Theodore, N. (2010) 'After neoliberalization?', Globalizations, 7, 3, 32745. 
Broady, D., Andersson, M. B., Börjesson, M., Gustafsson, J., Hultqvist, E. and Palme, M. (2000) Skolan under 1990-talet Sociala Förutsättningar och Utbildningsstrategier: Rapport till Kommittén Välfärdsbokslut, SEC Research Reports/Rapporter från Forskningsgruppen för utbildnings- och kultursociologi, No. 27, https://uu.divaportal.org/smash/get/diva2:328641/FULLTEXT01.pdf [accessed 18.10.2018].

Brown, D. K. (2001) 'The social sources of educational credentialism: status cultures, labor markets and organizations', Sociology of Education, 74, 19-34.

Burstein, P. (1998) 'Bringing the public back in: should sociologists consider the impact of public opinion on public policy?', Social Forces, 77, 27-62.

Castles, F.G. (1989) 'Explaining public education expenditure in OECD countries', European Journal of Political Research, 17, 4, 431-48.

Charteris-Black, J. (2004) Corpus approaches to critical metaphor analysis, Basingstoke: Palgrave Macmillan.

Christensson, F. (2015) 'Gör utbildning avgiftsfri för utländska studenter', Dagens Samhälle, 29 October.

Codd, J. (1988) 'The construction and deconstruction of educational policy documents', Journal of Education Policy, 3, 3, 235-47.

Cornelissen, J. P. (2005) 'Beyond compare: metaphor in organization theory', Academy of Management Review, 30, 751-64.

Cornellissen, J. P., Oswick, C., Thøger, L., Christensen, L. and Phillips, N. (2008) 'Metaphor in organizational research: context, modalities and implications for research', Organization Studies, 29, 1, 7-22.

Denhardt, R. B. and Denhardt, J. V. (2000) 'The new public service: serving rather than steering', Public Administration Review, 60, 549-59.

Drucker, P. (1993) Post-Capitalist Society, New York, Harper. 
Durnova, A. and Zittoun, P. (2011) 'Interpretive policy analysis in a French setting: The Fifth Interpretive Policy Analysis Conference, Grenoble, June 2010', Critical Policy Studies, 5, $2,103-05$.

Fauconnier, G. and Turner, M. (2002) The Way we Think: Conceptual Blending and the Mind's Hidden Complexities, New York, NY: Basic Books.

Fougner, T. (2006) 'The state, international competitiveness and neoliberal globalisation: is there a future beyond 'the competition state'?', Review of International Studies, 32, 1, 165-85.

Giroux, H. A. (2003) 'Utopian thinking under the sign of neoliberalism: towards a critical pedagogy of educated hope', Democracy and Nature, 9, 1, 91-105.

Goffman, E. (1974) Frame Analysis, New York: Harper Books..

Governmental Bill (2009) Proposition 2009/10:65. Konkurrera med Kvalitet - Studieavgifter för Utländska Studenter, Stockholm: Utbildningsdepartmentet, https://www.regeringen.se/49b729/contentassets/acdbd1cab8ab4144b1ec5f23f16e7937/ konkurrera-med-kvalitet---studieavgifter-for-utlandska-studenter-prop.-20091065 [accessed 18.10.2018].

Government Offices of Sweden (2009) Competing on the Basis of Quality - Tuition Fees for Foreign Students, Govt. Bill 2009/10:65, Stockholm: Government Offices of Sweden.

Government Offices of Sweden (2010) Fact sheet Competing on the Basis of Quality - Tuition Fees for Foreign Students, U10.007, Stockholm: Government Offices of Sweden.

Green, A. (1990) Education and State Formation: The Rise of Education Systems in England, France and the USA, London: Palgrave Macmillan.

Green, A. (1997) Education, Globalization and the Nation State, London: Palgrave MacMillan.

Greenwood, R., Raynard, M., Kodeih, F., Micelotta, E. and Lounsbury, M. (2011) 'Institutional complexity and organizational responses', Academy of Management Annals, 5, 317-71. 
Hega, G. M. and Hokenmaier, K. G. (2002) 'The welfare state and education: a comparison of social and educational policy in advanced industrial countries', German Policy Studies, 2, $1,1-28$.

Heidenheimer, A. J. (1981) 'Education and social security entitlements in Europe and America', in P. Flora and A. J. Heidenheimer (eds.), The Development of Welfare States in Europe and America, London: Transaction Books, 265-304.

Hjerm, M. and Schnabel, A. (2012) 'How much heterogeneity can the welfare state endure? The influence of heterogeneity on attitudes to the welfare state', Nations and Nationalism, 18, 2, 346-69.

Hobsbawm, E. (1994) Age of Extremes: The Short Twentieth Century 1914-1991, London: Abacus.

Hokenmaier, K. G. (1998) 'Social security vs educational opportunity in advanced industrial societies: is there a trade-off?', American Journal of Political Science 42, 2, 709-11.

Jaworski, A. and Coupland, N. (2000) 'Introduction: perspectives on discourse analysis' in A. Jaworskis and N. Couplands (eds.), The Discourse Reader, London/New York: Routledge, 1-38.

Jones, J. and Peccei, J. (2004) 'Language and politics', in L. Thomas, S. Wareing, I. Singh, J. Peccei, J. Thornborrow and J. Jones (eds.), Language, Society and Power, London: Routledge.

Kahlroth, M. (2012) 'Ny avgift för utländska studenter: Många avstår sin plats', https://www.scb.se/sv /Hitta-statistik/Artiklar/Manga-avstar-sin-plats-Ny-avgift-forutlandska-studenter/ [accessed 18.10.2018].

Keller, R. (2004) Diskursforschung. Eine Einführung für Sozialwissenschaftlerlnnen, Wiesbaden, VS Verlag für Sozialwissenschaften.

Keller, R. (2005) Wissensoziologische Diskursanalyse -Grundlegung eines Forschungsprogramms, Wiesbaden: Verlag für Sozialwissenschaften. 
Koller, V. (2005) 'Critical discourse analysis and social cognition: evidence from business media discourse.' Discourse and Society, 16, 2, 199-224.

de Koster, W., Achterberg, P. and van der Waal, J. (2012) 'The new right and the welfare state: the electoral relevance of welfare chauvinism and welfare populism in the Netherlands', International Political Science Review, 34, 1, 3-20.

Le Grand, J. (2003) Motivation, Agency and Public Policy: Of Knights and Knaves, Pawns and Queens, Oxford: Oxford University Press.

Lomer, S. (2017) 'Soft power as a policy rationale for international education in the UK: a critical analysis', Higher Education, 74, 4, 581-98.

Lundgren, K.-H. (2010) 'Avgifter ger sämre studiekvalitet: Op-ed', Sydsvenska Dagbladet, 23 January.

Mälardalens högskola (2010) 'Sverige inför avgifter men gör inget för att locka studenter', http://www.mdh.se/sverige-infor-avgifter-men-gor-inget-for-att-locka-studenter-1.21810 [accessed 20.10.2018].

Marginson, S. (2017) 'Limitations of human capital theory', Studies in Higher Education, 1-15.

Marshall, T. H. (2006 [1950]) 'Citizenship and social class', in C. Pierson and F. G. Castles (eds.), The Welfare State Reader, Cambridge/Malden: Polity Press.

Mau, S. and Burkhardt, C. (2009) 'Migration and welfare state solidarity in Western Europe', Journal of European Social Policy, 19, 3, 213-29.

McLaren, P (1986) Schooling as a Ritual Performance: Towards a political economy of Educational Symbols and Gestures, London: Routledge and Kegan Paul.

Morgan, G (1999) Organisationsmetaforer, Lund: Studentlitterarur

Morrow, R., and Torres, C. A. (2000). The state, globalization, and education policy in N. Burbules and C. A. Torres (Editors.), Globalization and education: Critical perspectives, New York and London: Routlege.

Mörck, H. V. (2010) 'Ingen vilja att internationalisera: Op-ed', Västerbottens-Kuriren, 23 June. 
Nilsson, M., Danielsson, J., Ericson, M. Wanngard, K. and Arroy, E. (2013) 'Studieavgifterna gör svenska lärosäten isolerade', Svenska Dagbladet, 5 April.

Nordensvärd, J. (2010) 'The consumer metaphor versus the citizen', in M. Molesworth, E. Nixon and R. Scullions (eds.), The Marketisation of Higher Education: The Student as Consumer, London: Routledge.

Nordensvärd, J. and Ketola, M. (2015) 'Nationalist reframing of the Finnish and Swedish welfare states - the nexus of nationalism and social policy in far-right populist parties', Journal of Social Policy and Administration, 49, 3, 357-75.

Östros, T. (2004) "Stärk högskolans internationella konkurrenskraft", Stockholm: Government Offices of Sweden

Östros, T. (2001) 'Skrämmande syn på högskolan - Op-ed'l', Sydsvenska Dagbladet, 19 November.

Pechar, H. and Andres, L. (2011) 'Higher-education policies and welfare regimes: international comparative perspectives', Higher education policy, 24, 1, 25-52.

Peck, J. (2010) Constructions of Neoliberal Reason, Oxford: Oxford University Press.

Peck, J. and Theodore, N. and Brenner, N. (2009) 'Neoliberal urbanism: models, moments, mutations', SAIS Review of International Affairs, 29, 1, 49-66.

Pollitt, C. and Bouckaert, G. (2004) Public Management Reform A Comparative Analysis, Oxford: Oxford University Press.

Porter, M. (1990) The Competitive Advantage of Nations, New York: Free Press

Rothstein, B., and Stolle, D. (2003) 'Social capital, impartiality and the welfare state: an institutional approach', in M. Hooghe and D. Stolle (eds.), Generating Social Capital, New York: Palgrave MacMillan, 191-210.

Ryner, J. M. (2002) Capitalist Restructuring, Globalisation and the Third Way: Lessons from the Swedish Model, London: Routledge. 
Sander, W. (2005) 'Theorie der politische bildung: geschichte - didaktische konzeptionen aktuelle tendenzen und probleme', in W. Sanders (ed.), Handbuch Politische Bildung. Bonn: Wochenschau Publishers.

Simons, M. and Masschelein, J. (2008) 'The governmentalization of learning and the assemblage of a learning apparatus', Educational Theory, 58, 4, 391-415.

Svenska Dagbladet (2011) 'Centerpartiet förväntas vilja slopa avgifter för utländska studenter', Svenska Dagbladet, 23 September.

Svenska Dagbladet (2008) 'Inte längre gratis studera i Sverige’, Svenska Dagbladet, 23 June.

Sveriges Radio (2013) '(S) vill slopa avgifter för utländska studenter', Sveriges Radio, 8 April.

Statens Offentliga Utredningar (SOU) (2000) Advantage Sweden - en kraftsamling för ökad rekrytering av utländska studenter till Sverige, : Government Offices of Sweden

Statens Offentliga Utredningar (SOU) (2006) Studieavgifter i Högskolan, Stockholm: Government Offices of Sweden

Thörn, H. and Larsson, B. (2012) 'Conclusions: re-engineering the Swedish welfare state', in B. Larsson, M. Letell and H. Thörn (eds.), Transformations of the Swedish Welfare State: From Social Engineering to Governance?, Basingstoke: Palgrave Macmillan.

Tight, M. (2013) 'Students: customers, clients or pawns?', Higher Education Policy, 26, 3, 291307.

Titmuss, R. M. (1974) Social Policy: An Introduction (eds. B. Abel-Smith and K. Titmuss). London: Allen and Unwin.

Todd, S., Barnoff, L., Moffatt, K., Panitch, M., Parada, H. and Strumm, B. (2017) 'A social work re-reading of students as consumers', Social Work Education, 36, 5, 542-56.

Universitetsläraren (2013) 'Socialdemokraterna föreslår förändring av studieavgifter', Universitetsläraren, 8, 13.

Van der Waal, J., Achterberg, P. and Houtman, D. et al. (2010), 'Some are more equal than others.' Economic egalitarianism and welfare chauvinism in the Netherlands, 
Journal of European Social Policy, 20, 4: 350-63.

Wanngård, K. (2012) 'Avgift på högskolan bör tas bort', Svenska Dagbladet, 27 February.

Weatherall, A. and Walton, M. (1999) 'The metaphorical construction of sexual experience in a speech community of New Zealand university students', British Journal of Social Psychology, 4, 479-98.

Werner, M. and Cornelissen, J. (2014) 'Framing the change: switching and blending frames and their role in instigating institutional change', Organization Studies, 35, 10, 1449-72.

Wielemans, W. (2000) 'European educational policy on shifting Sand?', European Journal for Education Law and Policy, 4, 1, 21-34.

Willemse, N. and De Beer, P. (2012) 'Three worlds of educational welfare states? A comparative study of higher education systems across welfare states', Journal of European Social Policy, 22, 2, 105-117. 